\title{
Aquatic fungal diversity in two freshwater ecosystems of Madhya Pradesh, India
}

\author{
Mehboob ${ }^{1}$, Ganie $\mathrm{AH}^{2 *}$, Dar $\mathrm{AR}^{3}$ and Soni $\mathrm{KK}^{4}$ \\ ${ }^{1}$ Rani Durgawati Vishwavidyalaya Jabalpur, M.P-India \\ ${ }^{2}$ Departments of Botany, University of Kashmir, Kargil Campus, India \\ ${ }^{3}$ Govt Degree College Bemina, J\&K-India \\ ${ }^{4}$ Forest Pathology Division, Tropical Forest Research Institute Jabalpur M.P-India
}

Mehboob A, Ganie AH, Dar AR, Soni KK 2021 - Aquatic fungal diversity in two freshwater ecosystems of Madhya Pradesh, India. Studies in Fungi 6(1), 116-137, Doi 10.5943/sif/6/1/6

\begin{abstract}
Aquatic fungi play an important role in litter decomposition in aquatic ecosystems. Keeping in view the importance of aquatic fungi, diversity of these organisms was studied in two freshwater ecosystems of Gaur River and Khurji Nala Jabalpur Madhya Pradesh India. During the present study, 34 fungal species and 6 chromista species have been recorded on decomposing substrates. Highest number of fungal genera were recorded in submerged litter samples of Tectona grandis followed by Dendroclamus strictus. The maximum percentage frequencies of various fungal species which colonize litter of different tree species were also recorded. The cluster analysis revealed that different fungal communities on various plant hosts vary significantly.
\end{abstract}

Key words - Colonization - decomposing substrate - fruits - litter - mixed twigs

\section{Introduction}

Aquatic fungi are very important for decomposition of litter in aquatic environments (Hyde \& Goh 1998a, b, Danger et al. 2016). There have been several reports of freshwater fungi on submerged wood in the tropics (Sudheep \& Sridhar 2013, Abdel-Aziz 2016) and subtropics (Cai et al. 2002, Luo et al. 2019). Fallen leaves, branches and twigs are important components of aquatic ecosystems regulating dynamics by increasing the retention of organic matter, and provide habitats for a large number of organisms, including fungi, insects and even fishes (Liu et al. 2012, Luo et al. 2016). Different species of Ascomycota and Basidiomycota occur most commonly on deciduous leaves that have fallen into streams, and perform a vital role in conditioning this plant detritus for consumption by stream invertebrates (Barlocher \& Marvanova 2010). Aquatic hyphomycetes colonize and grow on the decaying leaf litter and produce huge quantity of conidia in lotic habitats (Barlocher 2009). They are phylogenetically heterogeneous group with distinct conidial morphology (mainly sigmoid and multiradiate) adapted to streams and rivers involved in leaf litter decomposition (Ingold 1942, Barlocher 1992). They adapt ruderal strategy (substrate capture) by swift colonization on fast decomposing leaf detritus and asexually reproduce with rapid dispersal of spores to catch the available substrates (Barlocher 2009). Identifications are mainly based on the ontogeny and characteristic morphology of conidia (Ingold 1975, Marvanová 1997, Gulis et al. 2005). The sticky conidial tips facilitate anchoring and colorization of the leaf litter and other organic matter (Webster 1959, Read et al. 1992, Jones 2006, Dang et al. 2007, Kearns \& Barlocher 2008). Diversity of aquatic hyphomycetes in freshwaters is important for plant litter decomposition 
and several ecosystem functions (Barlocher \& Corkum 2003, Raviraja et al. 2005, Duarte et al. 2006). Baiting techniques are methods that allow the detection of fungal species in their respective environments (Czeczuga et al. 2009). Decomposition of these woody substrates is important in nutrient cycling (Harmon et al. 1986). The conditioned leaves are more palatable to stream insects (Graca 1993). Therefore, aquatic fungi are the main microbial decomposers of leaf litter in streams (Xia et al. 2017, Zhao et al. 2017, Jochen et al. 2019). Keeping in view the importance of fungi in aquatic ecosystems the diversity of these fungal species has been studied in two important fresh water bodies of Jabalpur (Madhya Pradesh), Central India.

\section{Material \& Methods}

The present study was carried out during 2011-2012 in two running water systems (Gaur River and Khurji Nala) of Madhya Pradesh with geo-coordinates of $21^{\circ} 08^{\prime} 54.30 \mathrm{~N}$ and $79^{\circ} 59^{\prime 2} 23.50 \mathrm{E}$ respectively The Gaur River is one of the most important river of Jabalpur- Mandla districts of Madhya Pradesh-India. This river is a subsidiary river of Narmada and it is in the way of Barela Mandir. The river flows from Niwas village (origin point) of Mandla district and joins Narmada River at Jabalpur. The river is the life line of the people residing in nearby villages mostly for various domestic activates. Khurji Nala is one of the important tributary of Gaur River and the water of the water body is used in various villages for agricultural purposes. Samples were collected from Gour River near Gour Bridge, Near TFRI campus and near Saliwara Village. Gour River lies on Mandla Road about $10 \mathrm{~km}$ southeast of Jabalpur. The area enjoys semi-arid type of climate with mean annual precipitation of $1358 \mathrm{~mm}$.

One hundred samples of submerged leaf litter, twigs, and fruits of various plant species (Tectona grandis, Dendrocalamus strictus, Magnifera indica, Eucalyptus hybrid and Dalbergia sissoo) along with water samples were collected randomly in sterilized polythene bags and were brought to laboratory for analysis and isolation of aquatic fungi. The samples ranged from twigs $(1 \mathrm{~cm}$ diam $\times 150 \mathrm{~cm}$ long), leaves (approx. $3 \mathrm{~cm} \times 15 \mathrm{~cm})$ to larger parts of $\operatorname{logs}(5 \mathrm{~cm}$ diam $\times 150 \mathrm{~cm}$ long). All the tree species of which the parts were used for study were growing on the margins of Gaur River and Khurji Nalla. Of the studied plant species some are native while some are exotic (Table 1).

Table 1 Distributional range of the selected plant species

\begin{tabular}{|l|l|l|}
\hline S. No. & Name of plant species & Native/Exotic \\
\hline 1 & Mangifera indica & Native \\
\hline 2 & Dalbergia sissoo & Native \\
\hline 3 & Eucalyptus hybrid & Exotic \\
\hline 4 & Dendrocalamus strictus & Native \\
\hline 5 & Tectona grandis & Native \\
\hline
\end{tabular}

For the isolation of fungi, direct method and Surface sterilization of Satyanarayana \& Johri (2005) were followed.

\section{Surface sterilization}

For surface sterilization decaying leaves and twigs were collected from Gaur River and Khurji Nala. The collected samples were washed with distilled water to remove attached debris and invertebrates. The samples were then cut into small pieces so as to put easily in surface sterilized petriplates. Molten PDA medium (Potato dextrose agar media) was poured into sterilized petriplates and allowed to solidify. Once the medium solidified, small pieces of samples were placed inside the plates. The plates containing medium plus samples were kept in a Biological Oxygen Demand (BDO) incubator and incubated at $25-27^{\circ} \mathrm{C}$ for seven days to one month. Then the samples were observed. 


\section{Direct observation}

In this method one drop of water samples were kept in a cavity slides and observed under microscope using different magnifications. Strain used in present study was cotton blue lactophenol. The decaying leaves and twigs collected from a local water body were cut into small pieces so as to accommodate inside the petriplates. Plates containing samples were kept in a BOD incubator and incubated at $25-27^{\circ} \mathrm{C}$ for seven days to one month. Then the samples were directly observed.

Identification of respective species was based on morphology and biometric data of conidiophores and conidia of the hyphomycetes. Various fungal species were identified by consulting standard literature, research papers and monographs (Nilsson 1964, Subramanian 1971, Booth 1971, 1977, Ellis 1971, 1976, Barnett \& Hunter 1972, Dudka 1974, 1985, Ingold 1975, Carmichael et al. 1980, Brathen 1984, Matsushima 1993, Khulbe 2001, Nagamani et al. 2006, Verma et al. 2008, Barbosa et al. 2013, Grossart et al. 2016, Sparrow 2018). For correct identification and authentication of fungal species we rendered the help of R. K. Verma of forest pathology division Tropical Forest Research Institute Jabalpur, India.

The percentage frequency of various fungal species was calculated by following (Agarwal 2008) method. The formula used is as follows:

$$
\% \text { Frequency }=\frac{\text { Number of occurrence of a species studied }}{\text { Total number of occurrence } \text { studied }} \times 100
$$

For the classification of fungi, Calabon et al. 2020, Hyde et al. 2017, 2020 and Mycobank (2021) were followed. The fungal cultures are deposited in Tropical Forest Research Institute Jabalpur M.P-India under the serial numbers from 1510-1695 (Table 2). Facesoffungi numbers were registered as mentioned in Jayasiri et al. (2015). Index Fungorun numbers were recorded from Index Fungorum (2020).

\section{Statistical analysis}

Cluster analysis for different fungal communities on various plants were analyzed using STAT 9.2 version

\section{Results}

During the present study 34 fungal species and 6 chromista species have been recorded on the water samples/decomposing substrates. The morphological features of the recorded fungal and chromista species are given below.

Absidia corymbifera (Cohn) Sacc. \& Trotter, in Saccardo, Syll. fung. (Abellini) 21: 825 (1912)

Index Fungorum Number: IF221175; Facesoffungi Number: FoF09589

Sporangiophores are hyaline to faintly pigmented, simple or sometimes branched arising solitary from the stolons, in groups of three or in whorls of up to seven. Rhizoids are very sparingly produced. Sporangia are small $(10-40 \mu \mathrm{m}$ in diameter) and are typically pyriform in shape with a characteristic conical-shaped columella and pronounced apophysis, often with a short projection at the top. Sporangiospores vary from subglobose to oblong-ellipsoidal $(3.0-7.0 \times 2.5-4.5 \mu \mathrm{m})$, are hyaline to light grey and are smooth-walled.

Material collected on 5 April 2011, isolated from submerged leaves of Dendrocalamus strictus, Gaur River, Jabalpur, Fig. 1.

\section{Absidia sp.}

Mycelium submerged as well as aerial. Sporangiophores straight, in groups of two to five. Sporangia pyriform, erect. Sporangiospores small, globose or oval, cylindrical. Zygospores formed on the stolons, surrounded by prominent circinate filaments which tend to envelop the zygospore. 
Material collected on 20 May 2011, isolated from submerged Eucalyptus hybrid dead leaves Gaur River, Jabalpur, Fig. 2.

Achlya debaryana Humphrey, Trans. Am. phil. Soc., New Series 17: 117 (1893) [1892]

Index Fungorum Number: IF210282; Facesoffungi Number: FoF09590

Hyphae coenocytic, up to $40 \mu \mathrm{m}$ wide. Zoosporangia cylindric, up to $250 \times 20-40 \mu \mathrm{m}$. Zoospores large, 12.1-14.6 $\mu \mathrm{m}$. Oogonia abundant, borne on short straight and lateral stalks of varying forms. Antheridia rarely present. Oospores eccentric, 1-2 in number in each oogonium, globose, $20-30 \mu \mathrm{m}$ in diameter.

Material collected on 9 March 2011, isolated from submerged leaves of Tectona grandis, Gaur River, Jabalpur, Fig. 3.

Achlya recurva Cornu, in Lambotte, Fl.myc. Belg. (Verviers): 120 (1880)

Facesoffungi Number: FoF09591

Mycelium extensive, diffuse, dense at periphery of the colony. Principle hyphae branched, 16-108 $\mu \mathrm{m}$ in diameter. Zoosporangia mostly clavate, rarely fusiform, straight, renewed sympodially. Zoospore discharge achlyoid, encysted spores 9-20 $\mu \mathrm{m}$ in diameter. Oogonia abundant, mostly lateral, rarely terminal, spherical, 25.2-64.8 $\mu \mathrm{m}$ in diameter covered with truncate wall ornamentation. Anthredia usually androgynous, rarely branched, anthredial cells clavate, filiform, simple.

Material collected on 20 May 2011, isolated from submerged mix fruits Gaur River, Jabalpur, Fig. 4.

Acremonium tectonae R.F. Castañeda [as 'Acromoniun'], Fungi Cubenses II (La Habana): 2 (1987)

Index Fungorum Number: IF131697; Facesoffungi number: FoF00880

Hyperparasite on rust spores. Rust sori become whitish due to infection. Mycelium colonizing rust spores, thin, hyaline, smooth walled, septate, branched. Conidiophores arising from mycelium wrapping rust spores, erect, smooth walled, generally one septate, hyaline. Conidia often hanging together in a bundle at the ends of phialides, hyaline, smooth, aseptate. Conidiophores, 14$35 \times 1-1.5 \mu \mathrm{m}$. Conidia, 2.5-7.5 × 1-2 $\mu \mathrm{m}$.

Material collected on 5 April 2011, isolated from submerged leaves of Dendrocalamus strictus, Gaur River, Jabalpur, Fig. 5.

Alternaria alternata (Fr.) Keissl., Beih. bot. Zbl., Abt. 2 29: 434 (1912).

Index Fungorum Number: IF119834; Facesoffungi Number: FoF03825

Conidiophores macronematous, rarely branched, dark brown with light brown tip and many conidial scars, $30-95 \times 3.5-5 \mu \mathrm{m}$. Conidia olivaceous brown with pale yellow tip, transverse, oblique and longitudinal septa, $12.5-32.5 \times 7.5-12.5 \mu \mathrm{m}$ with beak 7.5-30 $\mu \mathrm{m}$ long. Its distribution is cosmopolitan.

Material collected on 9 March 2011, isolated from submerged leaves of Tectona grandis, Gaur River, Jabalpur, Fig. 6.

Alternaria solani Sorauer, Z. PflKrankh. 6: 6 (1896)

Index Fungorum Number: IF216613; Facesoffungi Number: FoF09592

Conidiophores arising singly or in small groups, straight or flexuous, septate, rather pale brown or olivaceous brown, up to $110 \mu$ long, 6-10 $\mu$ thick. Conidia usually solitary, straight or slightly flexous, obclavate or with the body of the conidium oblong or ellipsoidal tapering to a beak which is commonly the same length as or rather longer than the body, pale or mid pale, golden or olivaceous brown, smooth, overall length usually 150-300 $\mu, 15-19 \mu$ thick in the broadest part, with 9-11 transverse and zero or a few longitudinal or oblique septa. 
Material collected on 9 March 2011, isolated from submerged leaves of Tectona grandis, Gaur River, Jabalpur, Fig. 7.

Althornia crouchii E.B.G. Jones \& Alderman, Nova Hedwigia 21(3-4): 382 (1972) [1971]

Index Fungorum Number: IF308522; Facesoffungi Number: FoF09593

Multicellular, globose bodies occurred on submerged plant materials, isolated as an oyster shell pathogen, but exists free floating in culture. Outer wall thick, brownish with centrally hyaline, granular, nutritive starch and glycogenic material, lacks bothrosomes and ectoplasmic net, producing dimorphic planonts.

Material collected on 20 May 2011, isolated from submerged leaves, fruits and twigs, Gaur River, Jabalpur, Fig. 8.

Aspergillus oryzae (Ahlb.) Cohn, Jber. schles. Ges. vaterl. Kultur 61: 227 (1884) [1883]

Index Fungorum Number: IF184394; Facesoffungi Number: FoF09594

Vegetative mycelium submerged, forming a tough basal felt, producing abundant longstalked conidial structures. Conidial heads radiate. Conidiophores mostly from submerged mycelium, erect, thin walled, hyaline, roughened and up to $5 \mathrm{~mm}$ long, 4-6 $\mu \mathrm{m}$ at the base, enlarging beneath the vesicles up to $25 \mu \mathrm{m}$. Vesicles subglobose, fertile over the entire surface, thin walled, collapsing easily. Phialides uniseriate in smaller heads, $10-15 \times 3.5-5.2 \mu \mathrm{m}$. Phialides biseriate in larger heads with metulae 7.5-12.5 $\times 3.8-5 \mu \mathrm{m}$. Conidia pyriform or elliptical when young, globose to subglobose at maturity, nearly smooth to roughened, 4.5-6.8 $\mu \mathrm{m}$, rarely up to 10 $\mu \mathrm{m}$. Sclerotia often produced, dark.

Material collected on 20 May 2011, isolated from submerged Eucalyptus hybrid dead leaves Gaur River, Jabalpur, Fig. 9.

Aspergillus nidulans (Eidam) G. Winter, Rabenh. Krypt.-Fl., Edn 2 (Leipzig) 1.2: 62 (1884)

Index Fungorum Number: IF182069; Facesoffungi Number: FoF09595

Conidiophores thick walled, smooth, sometimes verrucose, aseptate, geniculated, olivaceous brown, 12.5-162.5 $\times$ 3.75-6.25 mm. Conidial head yellowish green, 22.5-32.5 $\mathrm{mm}$ in diameter. Vesicle sub-globose, thick walled, about $7.5-12.5 \mathrm{~mm}$ in diameter, fertile only on the upper part. Phialides borne directly on vesicle. Conidia smooth or echinulate, globose, olivaceous green, 3-5 $\mu \mathrm{m}$ in diameter. Hulle cells globose, thick walled, $1.5-13.5 \mathrm{~mm}$ in diameter.

Material collected on 20 May 2011, isolated from submerged mix fruits, Gaur River, Jabalpur, Fig. 10.

Aspergillus terreus Thom, in Thom \& Church, Am. J. Bot. 5: 84 (1918)

Index Fungorum Number: IF191719; Facesoffungi Number: FoF09596

Conidial heads with conidia borne in definite characteristic compact columns up to $500 \times 30$ $50 \mu$ diameter. Conidiophores smooth, colourless, 100-250 $\times$ 4-6 $\mu$ diameter, vesicles dome shaped bearing tightly packed more or less parallel metulae over the upper two-thirds of the surface, 5-7 $\times$ 2-2.5 $\mu$. Phialides 5.5-7.5 $\times 1.5-2 \mu$. Conidia small, globose or nearly smooth, about $2 \mu$ diameter. In addition to these usual features, some globose to ovate or truncate heavy walled hyaline cells 6-7 $\mu$ diameter are produced singly or in clusters from the submerged mycelium.

Material collected on 20 May 2011, isolated from submerged leaves, fruits and twigs, Gaur River, Jabalpur, Fig. 11.

Aspergillus flavus Link, Mag. Gesell. naturf. Freunde, Berlin 3(1-2): 16 (1809)

Index Fungorum Number: IF209842; Facesoffungi Number: FoF09597

Mycelium white. Conidiophores macronematous, thick walled, smooth, simple, aseptate, pale yellow to light brown, 600-690 × 10-12.5 $\mu \mathrm{m}$. Conidial head globose, dark, 70-90 $\mu \mathrm{m}$. Vesicle globose, thick walled, entirely covered with phialides. Phialides borne directly on vesicle, club 
shaped, colourless to pale yellow, about $20 \mu \mathrm{m}$ in length. Conidia rounded, echinulate, light brown, 3.15-5 $\mu \mathrm{m}$ in diameter.

Material collected on 20 May 2011, isolated from submerged mix fruits, Gaur River, Jabalpur, Fig. 12.

Curvularia lunata Wakker) Boedijn, Bull. Jard. bot. Buitenz, 3 Sér. 13(1): 127 (1933)

Index Fungorum Number: IF269889; Facesoffungi Number: FoF00511

Mycelium septate, profusely branched, in the substratum sub-hyaline to light brown, at the surface brown, 2-5 $\mu$ wide. Conidiophores dark brown, unbranched, septate towards the tip, sometimes twisted, up to $270 \mu$ long, 2-4 $\mu$ wide. Conidia boat shaped, brown, 3- septate, the third cell from the base conspicously larger, broader and darker than the others, curved or sometimes straight, each with a sub-hyaline, rounded apical cell, and a subhyaline, somewhat obcoconical basal cell which bears a sear indicating point of attachment to the conidiophore, 17-35.8 $\mu$ long, 8 16.4 wide where widest.

Material collected on 5 April 2011, isolated from submerged leaves of Dendrocalamus strictus, Gaur River, Jabalpur, Fig. 13.

Cylindrocladium scoparium Morgan, Bot. Gaz. 17: 191 (1892)

Index Fungorum Number: IF152715; Facesoffungi Number: FoF09598

Mycelium superficial, immersed, septate, branched. Conidiophores macronematous, mononematous, erect and simple. Conidiogenous cell phialidic arranged in pencillate manner, each phialide cylindrical, smooth, 3-9 $\mu \mathrm{m}$ long, 2-5 $\mu \mathrm{m}$ broad, hyaline to subhyaline. Conidia phialidic elongated, smooth, 1-septate, 6-15 $\mu \mathrm{m}$ still long, 3-6 $\mu \mathrm{m}$ broad, hyaline to whitish.

Material collected on 20 May 2011, isolated from submerged leaves of Mangifera indica Gaur River, Jabalpur, Fig. 14.

\section{Cylindrosporium sp.}

Mycelium immersed, branched, septate, hyaline. Conidiomata acervular, white, slimy, subcuticular, separate or confluent, formed of pale brown to hyaline, thin walled texture angularis. Conidiophores hyaline, parallel, branched only at the base, 1-2 septate, smooth, formed the upper pseudoparenchyma. Conidiogenous cells enteroblastic, phialidic, integrated, cylindrical, hyaline and smooth. Conidia straight or slightly curved, aseptate, cylindrical, thin walled, smooth, hyaline, eguttulate.

Material collected on 20 May 2011, isolated from submerged twigs and branches, Gaur River, Jabalpur, Fig. 15.

\section{Cylindrocladium sp.}

Conidiophores erect or suberect, branching repeatedly near the apex to give a penicillate appearance. Phialides doliiform. Conidia aggregated in parallel bundles, cylindrical, straight or curved, mostly one septate. Chlamydospores commonly produced singly.

Material collected on 9 March 2011, isolated from submerged leaves of Tectona grandis, Gaur River, Jabalpur, Fig. 16.

Fusarium moniliforme J. Sheld., Nebraska Agric. Exp. Stat. Rep. 17: 23 (1904)

Index Fungorum Number: IF142842; Facesoffungi Number: FoF09599

Microconidiophores simple, lateral, subulate phialides formed on the aerial hyphae. Microconidia formed in chains, fusiform with a slightly flattened base, 0-1 septate, 10-15 × 2.5-3 $\mu \mathrm{m}$. Macroconidiophores consists of a single basal cell bearing 2-3 apical phialides. Macroconidia allantoid, tapered at the two ends, 3-6 septate, 17.5-47.5 × 3.5-5 $\mu \mathrm{m}$. Chlamydospores absent in both mycelium and conidia.

Material collected on 20 May 2011, isolated from submerged leaves of Dalbergia sissoo, Gaur River, Jabalpur, Fig. 17. 
Fusarium solani (Mart.) Sacc., Michelia 2(no. 7): 296 (1881)

Index Fungorum Number: IF190352; Facesoffungi Number: FoF01873

Mycelium striate, sparse, floccose, grey-white, Agar develop brownish-pinkish discolouration. Microconidia develop abundantly after 2-3 days, aseptate, hyaline, 10-22.5 $\times 3$ $4 \mu \mathrm{m}$, phialides $40-70 \times 2.5-3 \mu \mathrm{m}$. Macroconidia develop after 4-7 days from short multibranched conidiophores, which may form sporodochia, fusoid, 1-3 septate, 30-42.5 $\times 3.5-5 \mu \mathrm{m}$. Chlamydospores develop after 7-14 days, globose-oval, smooth-rough walled, terminal or intercalary.

Material collected on 9 March 2011, isolated from submerged leaves of Tectona grandis, Gaur River, Jabalpur, Fig. 18.

Fusarium oxysporum Schltdl., Fl. berol. (Berlin) 2: 139 (1824)

Index Fungorum Number: IF218372; Facesoffungi Number: FoF03824

Mycelium delicate, white or peach but usually with purple tinge, reverse pink, floccose. Microconidia borne on simple phialides, 10-12.5 $\times 2$ 2-2.5 $\mu \mathrm{m}$, arising laterally on the hyphae. Microconidia abundant, oval-ellipsoid, 0-1 septate, 5-15 $\times 2.5-3 \mu \mathrm{m}$. Macroconidia straight to slightly curved, 0-3 septate, $20-42.5 \times 4-5 \mu \mathrm{m}$.

Material collected on 20 May 2011, isolated from submerged Eucalyptus hybrid dead leaves Gaur River, Jabalpur, Fig. 19.

Fusarium equiseti (Corda) Sacc., Syll. fung. (Abellini) 4: 707 (1886)

Index Fungorum Number: IF199819; Facesoffungi Number: FoF09600

Mycelium aerial. Macroconidia only are produced and these may be variable in size and are produced from single solitary or grouped phialides. Conidia 4-7 septate, $22-60 \times 3.5-9 \mu$, often with elongated apical cell. Chlamydospores globose, $7-9 \mu$ diameter, intercalary, solitary in chains or clumps.

Material collected on 20 May 2011, isolated from submerged twigs and branches, Gaur River, Jabalpur, Fig. 20.

Fusarium pallidoroseum(Cooke) Sacc., Syll. fung. (Abellini) 4: 720 (1886)

Index Fungorum Number: IF232434; Facesoffungi Number: FoF09601

Mycelium aerial. Macroconidia of two types, primary and secondary. Primary macroconidia with wedge-shape foot cell, $0-5$ septate, $7.5-35 \times 2.5-4 \mu$. Secondary macroconidia with typical heeled foot-cell, 3-7 septate, 20-46 $\times 3-5.5 \mu$, formed from phialides usually grouped in sporodochia.

Material collected on 20 May 2011, isolated from submerged leaves of Dalbergia sissoo, Gaur River, Jabalpur, Fig. 21.

\section{Gilmaniella sp.}

Mycelium superficial and immersed. Hyphae at first colourless when young, smooth, later becoming brown and verruculose or finely echinulate, transverse septa often thick and very dark. Stroma, setae and hyphopodia absent. Conidiophores semi-macronematous, mononematous, straight. Conidia solitary, dry, simple, spherical, dark brown with a small but very distinct germ pore, smooth, zero septate.

Material collected on 20 May 2011, isolated from submerged leaves, fruits and twigs, Gaur River, Jabalpur, Fig. 22.

\section{Gliocladium sp.}

Hyphae hyaline, branched, septate. Conidiophores erect, arising from the substratum or from aerial hyphae, hyaline, simple or branched at the apex in a dense penicillate fashion bearing metulae and phialides, besides the penicillate conidiophores, primary, simply verticillate conidiophores may be present, ultimate sporogenous cells philiades. Phialides sometimes divergent, 
more often slightly or closely adpressed, bottle-shaped, frequently more convex on one side. Conidia hyaline or pigmented, 0 -septate, ovoid or sometimes flattened on one side.

Material collected on 20 May 2011, isolated from submerged mix fruits, Gaur River, Jabalpur, Fig. 23.

Monodictys levis (Wiltshire) S. Hughes, Can. J. Bot. 36: 785 (1958)

Index Fungorum Number: IF301287; Facesoffungi Number: FoF09602

Conidia clavate or pyriform, few - celled, often constricted at the septa, clear pale to mid brown or greyish brown, smooth, base conico-truncate, 17-30 $\times 15-19 \mu$. Phialides sometimes present, phialoconidia catenate or in slimy heads, hyaline, $2-4 \times 1.5-2 \mu$.

Material collected on 9 March 2011, isolated from submerged leaves of Tectona grandis, Gaur River, Jabalpur, Fig. 24.

Paecilomyces variotii Bainier Bull. Soc. mycol. Fr. 23(1): 27 (1907)

Index Fungorum Number: IF248517; Facesoffungi Number: FoF09603

Chlamydospores borne singly or in short chains, intercalary or terminal, more or less globose, brown, 4-8 $\mu \mathrm{m}$ in diameter. Fertile hyphae usually short chains, intercalary or terminal, more or less globose. Conidiophores repeatedly verticillate or freely and irregularly branched, up to $325 \mu \mathrm{m}$ long. Metuale divergent. phialides irregularly distributed along the fertile hyphae, with long acuminate conidium bearing tubes usually bent away from the axis of the cell and widely divergent at the apex, bearing long, tangled chains of conidia, 11.5-20.2 $\times 2.4-3 \mu \mathrm{m}$.

Material collected on 5 April 2011, isolated from submerged leaves of Dendrocalamus strictus, Gaur River, Jabulpur, Fig. 25.

Penicillium chrysogenum Thom, Bull. U.S. Department of Agriculture, Bureau Animal Industry 118: 58 (1910)

Index Fungorum Number: IF165757; Facesoffungi Number: FoF09604

Conidiation light to moderate, greyish to dull green or near glaucous blue-green. In some isolates conidation appears more yellow-green because of the presence of exudate, in others becoming buff or brown centrally, conidia en masse blue or blue-green. Exudates characteristically produced, moderately abundant to copious, pale to bright yellow or yellow brown; soluble pigment bright yellow, sometimes absent.

Material collected on 9 March 2011, isolated from submerged leaves of Tectona grandis, Gaur River, Jabalpur, Fig. 26.

\section{Penicillium sp.}

Vegetative hyphae creeping, septate. Conidiophores usually conspicuous, more or less erect, branched, series of branches giving characteristic brush like penicillus. Phialides borne in groups directly at the apex of the conidiophores or branches of the conidiophores. Conidia borne in long chains, globose to ovoid.

Material collected on 20 May 2011, isolated from submerged leaves of Mangifera indica Gaur River, Jabalpur, Fig. 27.

Periconia madreeya Subram., J. Indian bot. Soc. 34: 355 (1955)

Index Fungorum Number: IF302485, Facesoffungi Number: FoF09605

Conidiophores without apical heads of conidia. Stipe usually unbranched and sterile at the tip, but occasionally branched or producing conidia at the tip. Stipe erect, straight or bent, up to 12septate, pale brown below, dark brown above and thick walled. Sporogenous cell produced singly or in small groups of 2-4 from cells towards the upper half or central part of the stripe. Conidia produced acropetally in single or branched chains from the sporogenous cells but maturing from the apex backward in the chains, dark brown, one celled, globose, thick walled, verrucose to minutely echinulate, $8-12 \mu$ in diameter. 
Material collected on 20 May 2011, isolated from submerged leaves, fruits and twigs, Gaur River, Jabalpur, Fig. 28.

Phoma exigua Sacc., Michelia 1(no. 5): 525 (1879)

Index Fungorum Number: IF375167; Facesoffungi Number: FoF09606

Mycellium aerial, not concentrically zoned. Conidia 5.5-10 $\times 2.5-3.5 \mu$, straight or slightly curved, ellipsoid or cylindrical, often biguttulate and becoming one septate.

Material collected on 9 March 2011, isolated from submerged leaves of Tectona grandis, Gaur River, Jabalpur, Fig. 29.

Pythium carolinianum V.D. Matthews, Stud. genus Pythium: 71 (1931)

Index Fungorum Number: IF259923; Facesoffungi Number: FoF09607

Mycelium well developed, intra or extramatrical, hyphae large, branching irregular and free. Sporangia mainly terminal, sometimes intercalary, spherical to elongated with well-developed papilla, 20-30 $\mu \mathrm{m}$ in diameter. Secondary sporangia often formed by proliferation through the primary ones. Zoospores numerous in a vesicles, biciliate. Oogonia numerous, spherical, terminal or intercalary, smooth walled, 14-21 $\mu \mathrm{m}$ in diameter. Antheridia 1-4 per oogonium, borne from the same or another hypha as the oogonium. Oospores forming one in each oogonium, not filling the oogonium, spherical, smooth, 12-19.2 $\mu \mathrm{m}$ in diameter.

Material collected on 20 May 2011, isolated from submerged twigs and branches, Gaur River, Jabalpur, Fig. 30.

\section{Pythium debaryanum R. Hesse (1874)}

Index Fungorum Number: IF176113; Facesoffungi Number: FoF09608

Mycelium with abundant branching, short side branches thread-like and curved. Sporangia always spherical, terminal or lateral. Conidia colourless, terminal or intercalary with a moderately thick wall. Oogonia spherical and terminal on short side branches, with a smooth, thin entire wall, 20-55 $\mu \mathrm{m}$ in diameter. Antheridia many, arising from the oogonial stalk. Oospores aplerotic, with a small eccentrically placed vacuole, wall clear, thin, smooth.

Material collected on 20 May 2011, isolated from submerged leaves, fruits and twigs, Gaur River, Jabalpur, Fig. 31.

\section{Pythium sp.}

Hyphae coenocytic. Sporangia thread like, cylindrical, terminal or intercalary. Zoospores formed in a vesicle at the tip of the evacuation tube arising from the sporangium. Oogonia terminal or intercalary, mostly contain only one oospore. Antheridia club shaped. Oospore spherical with large central colourless fat-drop.

Material collected on 20 May 2011, isolated from submerged leaves of Mangifera indica Gaur River, Jabalpur, Fig. 32.

Rhizopus oryzae Went \& Prins. Geerl., Verh. K. Akad. Wet.,tweede sect. 4(2): 16 (1895)

Index Fungorum Number: IF433253; Facesoffungi Number: FoF09609

Mycelium snow-white in early stages, at maturity black, stolons little developed not forming nodes regularly. Rhizoids pale, with 4-8 branches, developed at nodes bearing sporangia. Stolons of sporangiophores often prostrate, rarely single, forming umbels or corymbs on their stolons. Sporangia spherical, dark-brown, 85-250 $\mu \mathrm{m}$ in diameter. Columella and apophysis together soon collapse after spore release. Spores 40-75 $\mu \mathrm{m}$ high, 60-100 $\mu \mathrm{m}$ in width. Sporangiospores irregular in shape, angular, ovate or subglobose with obtuse angles. Zygospores round, oval or without definite shape, 120-140 $\mu \mathrm{m}$. Suspensors equal or different in size and shape. Chlamydospores always present singly or in short chains, $16-32 \mu \mathrm{m}$ in diameter.

Material collected on 9 March 2011, isolated from submerged leaves of Tectona grandis, Gaur River, Jabulpur, Fig. 33. 
Rhizoctonia solani J.G. Kühn, Ann. Sper. agr., N.S.: 224 (1858)

Index Fungorum Number: IF229666; Facesoffungi Number: FoF09610

Mycelium highly variable in appearance depending on its age, composed at first of colourless hyphae, later becoming yellowish and then deep brown in colour, the cell contents becoming granular and finally disappearing. Hyphal branches typically constricted at points of origin. Sclerotia irregular in shape, black, closely adpressed to the host surface, varying in size from that of a pinhead to that of a pea.

Material collected on 20 May 2011, isolated from submerged twigs and branches, Gaur River, Jabalpur, Fig. 34.

\section{Scopulariopsis sp.}

Mycelium partly superficial partly immersed. Stroma none. Setae and hyphopodia absent. Conidiophores macronematous or semimacronematous, mononematous, branched with branches mostly restricted to the apical region or unbranched. Conidiogenous cells monoblastic, sometimes integrated, terminal, more commonly discrete and arranged penicillately, percurrent, closely annellate, ampulliform, lageniform, subulate or cylindrical. Conidia catenate, dry, acrogenous, simple, ellipsoidal, obovoid, pyriform or subspherical, truncate with a rim at the base, colourless to brown, smooth or verrucose, zero septate.

Material collected on 9 March 2011, isolated from submerged leaves of Tectona grandis, Gaur River, Jabalpur, Fig. 35.

Syncephalastrum racemosum Cohn ex J. Schröt., in Cohn, Krypt.-Fl. Schlesien (Breslau) 3.1(916): 217 (1886) [1889]

Index Fungorum Number: IF201627; Facesoffungi Number: FoF09611

Turf at first white, later grey, up to $6 \mathrm{~mm}$ high, mycelium with pseudoholdfast, which connect with short rhizoids that soon become overgrown. Conidiophores, vigorous, at first unbranched then laterally branched with strongly curved lateral. Fruiting head globose or oval, 22-70 mm wide brown to grey with numerous small warts to which the merosporangia are attached. Spores 5-10 per sporangia, irregular in size, mostly globose, 2.5-5 mm diameter.

Material collected on 5 April 2011, isolated from submerged leaves of Dendrocalamus strictus, Gaur River, Jabalpur, Fig. 36.

Trichoderma aureoviride Rifai, Mycol. Pap. 116: 34 (1969)

Index Fungorum Number: IF340298; Facesoffungi Number: FoF09612

Mycelium form compact networks, hyphae branched, septate, colourless. Conidiation forming compact dull green tufts or pustules. Chlamydospores sparse, intercalary on submerged creeping mycelium, smooth, up to $10 \mu \mathrm{m}$. Conidiophores flexuous, form compact distinct zones or irregularly dispersed on the surface of the colony. Simple conidiophores may arise later outside the primary conidiophores, main conidiophores slender, regularly, vertically branched, side branches arise above the septa in groups of 2-3, in turn the side branches put forth smaller branches again, length of the side branches increases with the distance away from the apex which results in coniferlike appearance, the branches bend little towards the bearer and all the branches end in philiades. Philiades long and slender, lageniform to subulate. Conidia smooth walled, obovoid or occasionally obovote with distinct truncate base, 3-4.3 $\times 2-3 \mu \mathrm{m}$.

Material collected on 9 March 2011, isolated from submerged leaves of Tectona grandis, Gaur River, Jabalpur, Fig. 37.

Trichoderma harzianum Rifai, Mycol. Pap. 116: 38 (1969)

Index Fungorum Number: IF340299; Facesoffungi Number: FoF09613

Mycelium creeping, septate, branched, 2-3 $\mu \mathrm{m}$ broad. Conidiophores micronematous or semimicronematous, simple or branched, 20-30 $\mu \mathrm{m}$ long, 2-3 $\mu \mathrm{m}$ broad, producing phialidic. Conidiogenous cells phialidic terminal or in verticils on the conidiophores laginiforms with long 
neck, $8-12 \mu \mathrm{m}$ long, $2-4 \mu \mathrm{m}$ in the broadest up to $5 \mu \mathrm{m}$ broad in the pointed neck like region. Conidia greenish held in mucilaginous mass to form a head consisting 5-10 conidia.

Material collected on 9 March 2011, isolated from submerged leaves of Tectona grandis, Gaur River, Jabalpur, Fig. 38.

Trichoderma viride Pers., Neues Mag. Bot. 1: 92 (1794)

Index Fungorum Number: IF181950; Facesoffungi Number: FoF09614

Mycelium superficial, creeping, hyphae septate, branched. Conidiophores, macronematous, semimacronematous, mononematous, erect or branched, 10- ${ }^{`} 15 \mu \mathrm{m}$ long, 2.8-5.6 $\mu \mathrm{m}$ broad. Conidia zero septate dry or slimy, solitary or in chains or in cluster of conidial mass $2.8-4.2 \mu \mathrm{m}$ in diameter, smooth or slightly verrucose bright green in colour.

Material collected on 9 March 2011, isolated from submerged leaves of Tectona grandis, Gaur River, Jabalpur, Fig. 39.

Verticillium nubilum Pethybr., Trans. Br. mycol. Soc. 6(2): 117 (1919) [1918]

Index Fungorum Number: IF225664; Facesoffungi Number: FoF09615

Cultures growing readily on PDA. Mycelium becoming weakly to compactly white. Flocculose brownish to cream, blackish in reverse after 2-3 weeks with the formation of chlamydospores. Hyaline sectors frequently produced.

Conidiophores abundantly in recent isolates, erect, hyaline, verticillately branched, 1-3 phialides arising at each node. Phialides variable in size, mainly $25-35 \times 1-2.5 \mu$. Conidia arise singly at the apices of phialides, ellipsoidal, hyaline, simple, sometimes, one septate.

Resting mycelium absent. Chlamydospores abundantly produced singly or in chains, 8.5$17.5 \mu$. Microsclerotia absent, globose to sub globose singly or in chains.

Material collected on 5 April 2011, isolated from submerged leaves of Dendrocalamus strictus, Gaur River, Jabalpur, Fig. 40.

The samples collected from Gaur River were observed by both direct method and baiting technique. By direct method the collected samples which include submerged leaves, fruits, and twigs revealed that five fungal species (Aspergillus flavus, Aspergillus terreus, Gilmaniella sp., Periconia madreeya, Rhizoctonia solani) and two chromista species (Althornia crouchii, Pythium debaryanum) are present on these plant parts.

The baiting method was carried out on the samples which include: leaves, twigs, branches and mixed fruits of selected plant species and during the study 31 fungal species and 4 chromista species have been isolated, the voucher specimens of all the species have been deposited at the Tropical Forest Research Institute Jabalpur M.P-India (Table 2).

The diversity of fungal and chromista species on different plant substrata of 5 taxa from 2 water bodies of Jabalpur MP- India is depicted Fig. 41A-E.

Present study revealed that maximum number of fungal genera were recorded from submerged litter samples of Tectona grandis (13 genera) (Fig. 41A) followed by submerged litter of Dendrocalamus strictus (09) (Fig. 41B) Mangifera indica (03) Eucalyptus hybrid (3 genera) (Fig. 41C, D). The leaves of Tectona grandis were colonized by more number of fungi belonging to Ascomycota. The maximum percentage frequency of the fungi which colonize on litter of $T$. grandis was recorded to be Monodictys levis (46.66), followed by Phoma exigua (40), Rhizopus oryzae (33.33) and Alternaria alternata (20). The two species of the genus Trichoderma, namely: $T$. viride and $T$. aureoviride also colonize the litter of $T$. grandis. Similarly the other plant species studied presently which include: Dendrocalamus strictus, Eucalyptus hybrid, Dalbergia sissoo, Mangifera indica have also been colonized by different fungal species (Fig. 41).

The twigs and branches of these plant species were colonized by different fungal species and the percentage frequency was depicted in (Fig. 42A). Mixed fruit of different plant species like Terminalia arjuna, Butea monospermum, Pongamia pinnata were analyzed for colonization of various aquatic fungi. It has been observed that 3 fungal species (Aspergillus nidulans, Aspergillus 
flavus and Gliocladium sp.) colonize the mixed fruits of aforementioned angiospermic plant species (Fig. 42B).
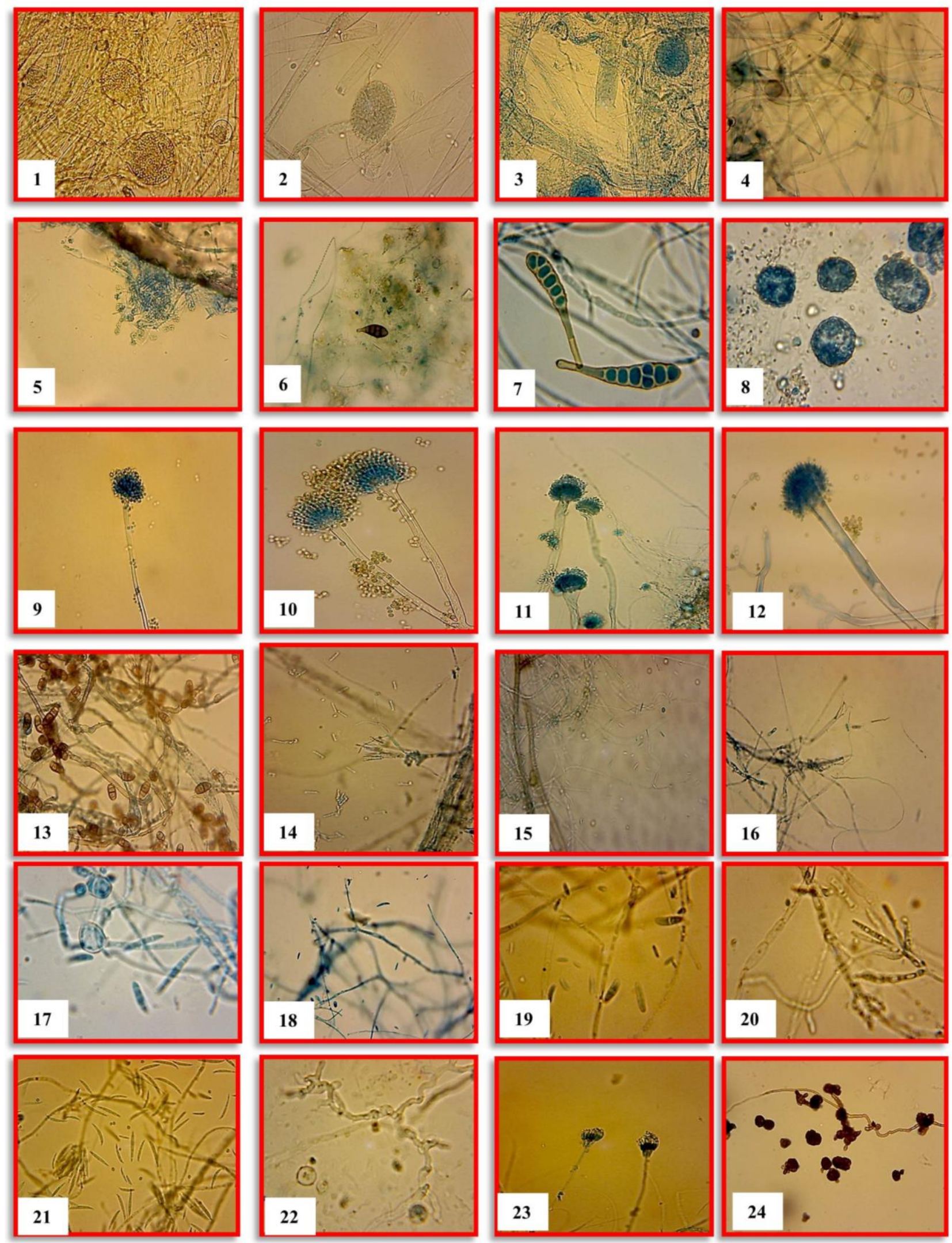

Figs 1-40 - The diversity of fungal and chromista species recorded from two freshwater ecosystems. 1 Absidia corymbifera. 2 Absidia sp. 3 Achlya debaryana. 4 Achlya recurve. 5 Acremonium tectonae. 6 Alternaria alternate. 7 Alternaria solani. 8 Althornia crouchii. 
9 Aspergillus oryzae. 10 Aspergillus nidulans. 11 Aspergillus terreus. 12 Aspergillus flavus. 13 Curvularia lunata. 14 Cylindrocladium scoparium. 15 Cylindrosporium sp. 16 Cylindrocladium sp. 17 Fusarium moniliforme. 18 Fusarium solani. 19 Fusarium oxysporum. 20 Fusarium equiseti. 21 Fusarium pallidoroseum. 22 Gilmaniella sp. 23 Gliocladium sp. 24 Monodictys levis. 25 Paecilomyces variotii. 26 Penicillium chrysogenum. 27 Penicillium sp. 28 Periconia madreeya. 29 Phoma exigua. 30 Pythium carolinianum. 31 Pythium debaryanum. 32 Pythium sp. 33 Rhizopus oryzae. 34 Rhizoctonia solani. 35 Scopulariopsis sp. 36 Syncephalastrum racemosum. 37 Trichoderma aureoviride. 38 Trichoderma harzianum. 39 Trichoderma viride. 40 Verticillium nubilum.
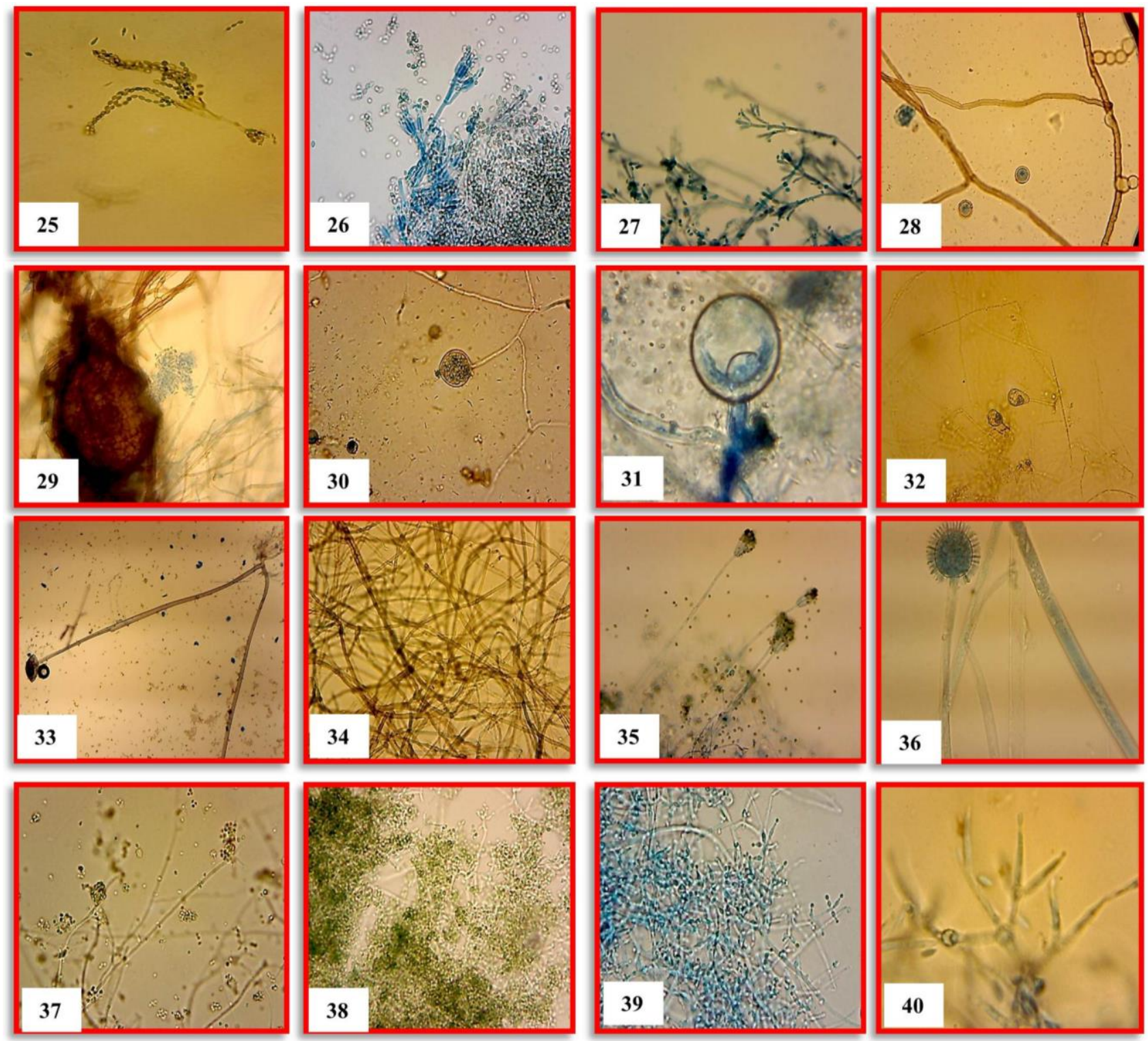

Figs 1-40 - Continued.

Table 2 Different fungal species isolated from different spermatophytes

\begin{tabular}{|l|l|l|l|l|}
\hline Kingdom & Taxon & $\begin{array}{l}\text { Isolated from plant } \\
\text { material }\end{array}$ & $\begin{array}{l}\text { Date of isolation/ } \\
\text { collection }\end{array}$ & $\begin{array}{l}\text { Herbarium } \\
\text { No. (TF) }\end{array}$ \\
\hline \multirow{3}{*}{ Fungi } & Aspergillusflavus & $\begin{array}{l}\text { Tectona grandis, mix } \\
\text { fruits }\end{array}$ & 20 May 2011 & 1570 \\
\cline { 2 - 5 } & Alternariaalternata & Tectona grandis & 9 March 2011 & 1556 \\
\cline { 2 - 5 } & Alternariasolani & Tectona grandis & 9 March 2011 & 1557 \\
\hline
\end{tabular}


Table 2 Continued.

\begin{tabular}{|c|c|c|c|c|}
\hline Kingdom & Taxon & \begin{tabular}{|l|} 
Isolated from plant \\
material
\end{tabular} & $\begin{array}{l}\text { Date of isolation/ } \\
\text { collection }\end{array}$ & $\begin{array}{l}\text { Herbarium } \\
\text { No. (TF) }\end{array}$ \\
\hline & Cylindrocladium sp. & Tectona grandis & 20 May 2011 & 1566 \\
\hline & Fusarium solani & \begin{tabular}{|l|} 
Tectona grandis, \\
Dendrocalamusstrictus
\end{tabular} & 9 March 2011 & 1634 \\
\hline & Monodictys levis & Tectona grandis & 9 March 2011 & 1734 \\
\hline & Penicilliumchrysogenum & Tectona grandis & 9 March 2011 & 1744 \\
\hline & Phoma exigua & Tectona grandis & 9 March 2011 & 1812 \\
\hline & Rhizopusoryzae & $\begin{array}{l}\text { Tectona grandis, } \\
\text { Dendrocalamusstrictus, } \\
\text { Mangiferaindica }\end{array}$ & 9 March 2011 & 1849 \\
\hline & Scopulariopsis sp. & Tectona grandis & 9 March 2011 & 1895 \\
\hline & Trichodermaaureoviride & Tectona grandis & 9 March 2011 & 1904 \\
\hline & Trichodermaharzianum & Tectona grandis & 9 March 2011 & 1903 \\
\hline & Trichoderma viride & Tectona grandis & 9 March 2011 & 1907 \\
\hline & Absidia corymbifera & Dendrocalamusstrictus & 5 April 2011 & 1510 \\
\hline & Acremonium tectonae & Dendrocalamusstrictus & 5 April 2011 & 1545 \\
\hline & Curvularia lunata & Dendrocalamusstrictus & 5 April 2011 & 1602 \\
\hline & Fusarium pallidoroseum & \begin{tabular}{|l} 
Dendrocalamusstrictus, \\
Dalbergiasissoo
\end{tabular} & 20 May 2011 & 1670 \\
\hline & Paecilomyces variotii & Dendrocalamusstrictus & 5 April 2011 & 1739 \\
\hline & $\begin{array}{l}\text { Syncephalastrum } \\
\text { racemosum }\end{array}$ & Dendrocalamusstrictus & 5 April 2011 & 1901 \\
\hline & Verticillium nubilum & Dendrocalamusstrictus & 5 April 2011 & 1921 \\
\hline & Cylindrocladium scoparium & Mangiferaindica & 20 May 2011 & 1604 \\
\hline & Penicillium sp. & Mangiferaindica & 20 May 2011 & 1636 \\
\hline & Absidia sp. & Eucalyptus hybrid & 20 May 2011 & 1610 \\
\hline & Aspergillus oryzae & \begin{tabular}{|l} 
Eucalyptus hybrid, \\
Dalbergiasissoo
\end{tabular} & 20 May 2011 & 1564 \\
\hline & Fusarium oxysporum & Eucalyptus hybrid & 20 May 2011 & 1639 \\
\hline & Fusarium moniliforme & Dalbergiasissoo & 20 May 2011 & 1605 \\
\hline & Cylindrosporium sp. & twigs and branches & 20 May 2011 & 1640 \\
\hline & Fusarium equiseti & twigs and branches & 20 May 2011 & 1649 \\
\hline & Rhizoctonia solani & twigs and branches & 20 May 2011 & 1894 \\
\hline & Aspergillus nidulans & Mix fruits & 20 May 2011 & 1567 \\
\hline & Gliocladium sp. & Mix fruits & 20 May 2011 & 1721 \\
\hline \multirow[t]{4}{*}{ Chromista } & Achlya debaryana & \begin{tabular}{|l|} 
Tectona grandis, \\
Dendrocalamusstrictus, \\
Eucalyptus hybrid, \\
Dalbergiasissoo
\end{tabular} & 9 March 2011 & 1511 \\
\hline & Pythium sp. & Mangiferaindica & 20 May 2011 & 1641 \\
\hline & Pythium carolinianum & Twigs and branches & 20 May 2011 & 1845 \\
\hline & Achlya recurva & Mix fruits & 20 May 2011 & 1522 \\
\hline
\end{tabular}

The cluster analysis data on the basis of presence and absence of fungal and chromista species is depicted on various plant hosts in Figs 43, 44. The study revealed that the different fungal communities on various plant hosts vary significantly. 

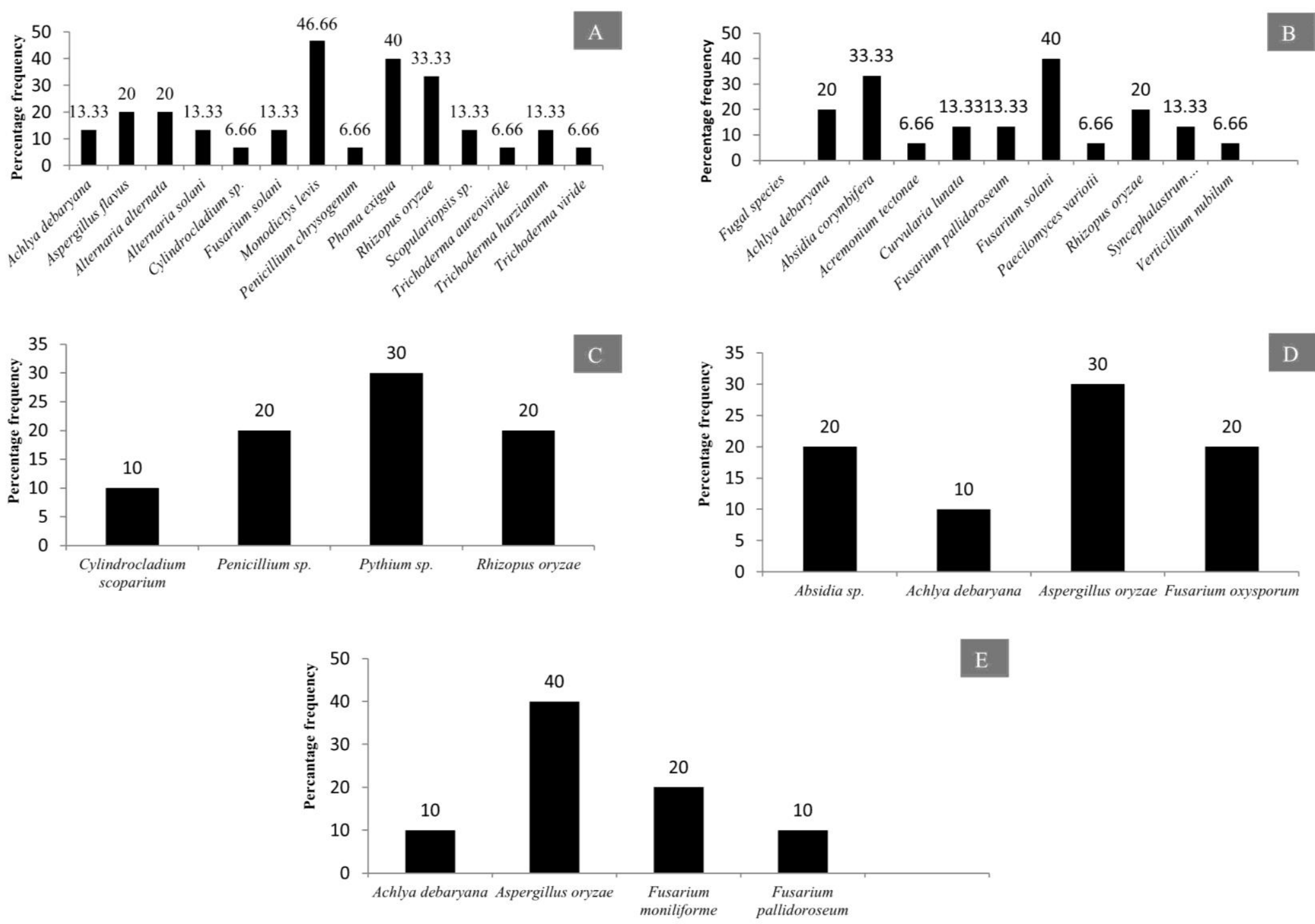

Fig. 41 - Percentage frequency of fungi and chromista isolated from submerged and decomposed leaves of various angiospermic plant species. A Tectona grandis. B Dendrocalamus strictus. C Mangifera indica. D Eucalyptus sp. E Dalbergia sissoo. 

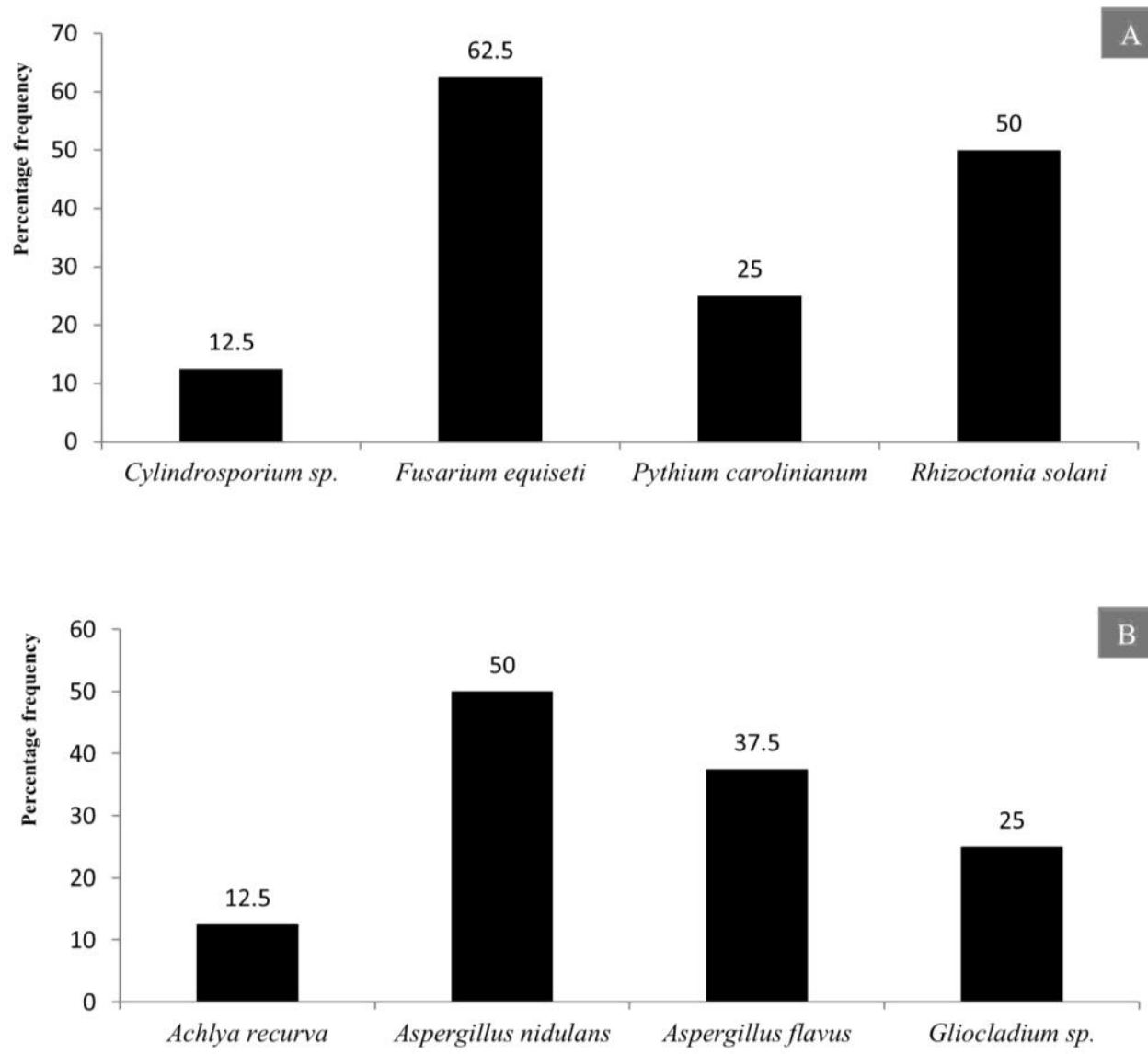

Fig. 42 - Percentage frequency of fungi and chomista isolated from submerged and decomposed mixed plant parts. A Twigs and branches. B Mixed fruits.

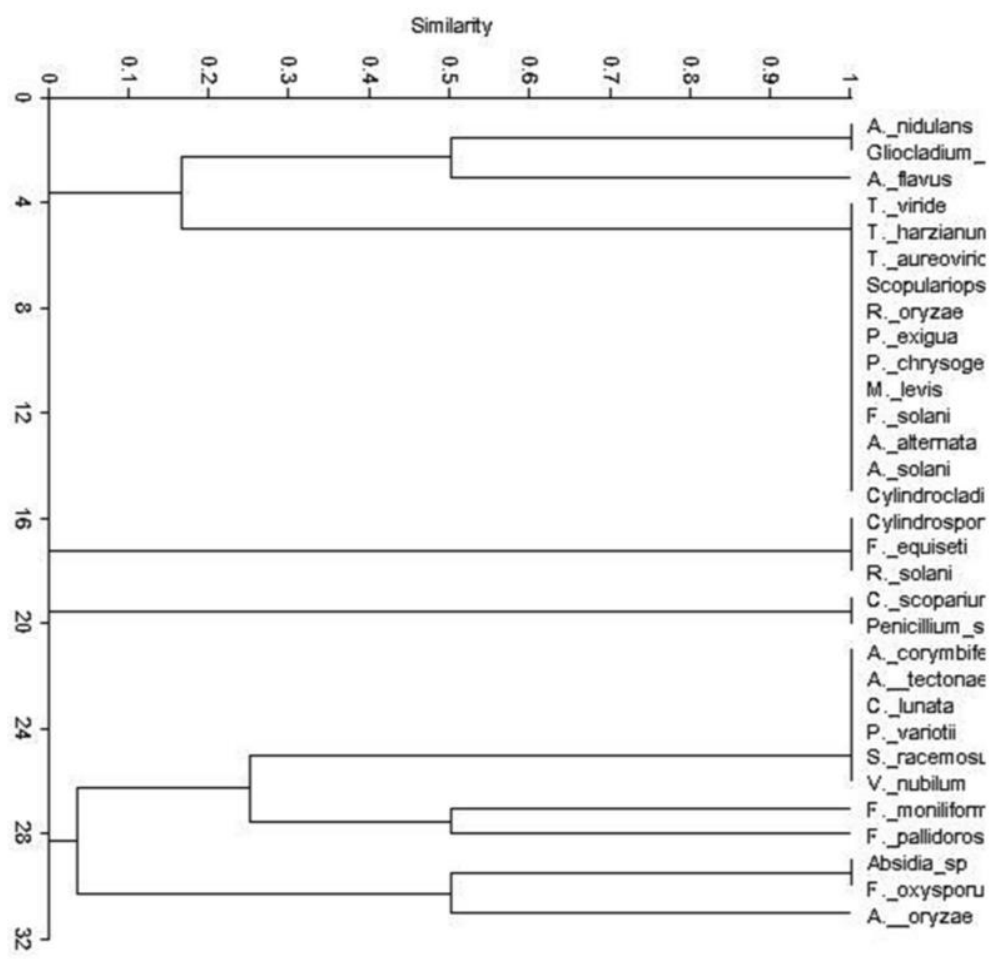

Fig. 43 - Cluster analysis of different fungal species colonizing various higher plants. 


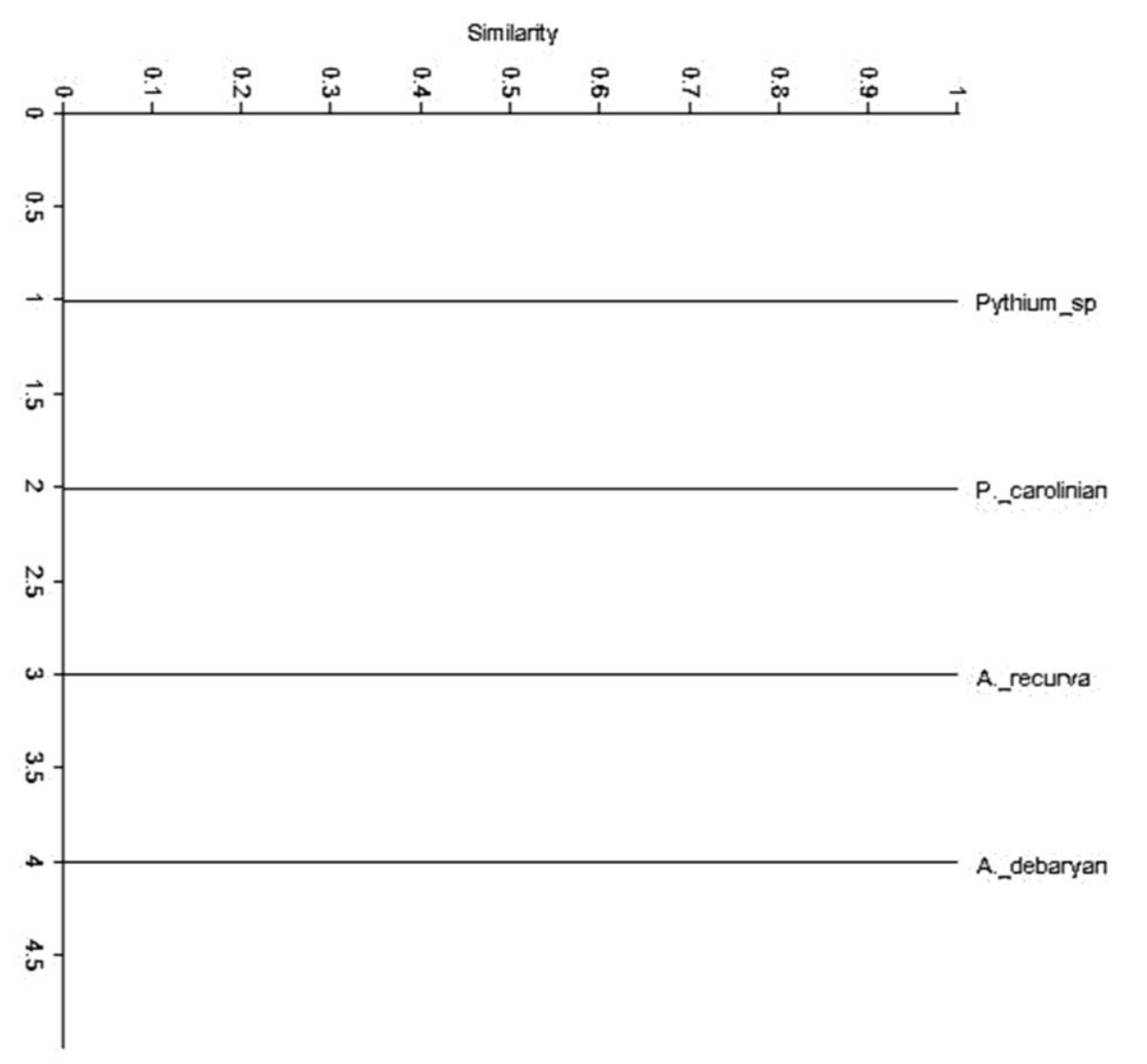

Fig. 44 - Cluster analysis of different chromista species colonizing various angiospermic plants.

\section{Discussion}

The present study revealed that the fungal species isolated from freshwater aquatic habitats are distributed in 21 genera and 34 species, of these 29 species are distributed in 12 families and the remaining 5 species are listed as incertae sedis (uncertain position) according to Index Fungorum (2020) (Table 3). During the present study it has also been observed that 6 species belong to chromista which are distributed in 3 genera and 3 families. It has been observed that Achylya debaryana colonizes maximum number of angiospermic species followed by Rhizopus oryzae (Fig. 45). The species of Ascomycota colonize large number of tree species as compared to Oomycota, Zygomycota, Basidiomycota and Labyrinthulomycota (Fig. 46), our results are in conformity with some previous studies (Abdel-Aziz 2016, Masigol et al. 2019, Khallil et al. 2020). Borse (2000) reported that Basidiomycota are not frequently involved in the succession and decomposition of aquatic plant substrata. From river Nile, Ninety-nine taxa representing 42 sexual Ascomycetes, 55 asexual taxa and two Basidiomycetes were identified from 959 fungal collections recorded from 400 submerged samples from fresh water ecosystems (Abdel-Aziz 2016). Khallil et al. (2020) also observed Achlya, Dictyuchus, and Pythium as the most common genera in aquatic systems, whereas some fugal genera like Brevilegnia and Pythiopsis were the least frequent ones. The diversity of aquatic fungal and chromista species observed during the present study were similar to that of Borse (1987, 1988), Borse et al. (1999) and Schoenlein-Crusius \& Milanez (1998). Pythium spp., Aspergillus spp and Achlya spp. are dominant colonizers on aquatic submerged plant parts (El-Hissy et al. 2000, Kiziewicz 2004, Paliwal \& Sati 2009). The main role of the freshwater Ascomycete, Basidiomycetes and Mitosporic fungi in freshwater ecosystems is in the degradation and decomposition of dead plant material (Goh \& Hyde 1996). Aquatic fungi are also regarded as the dominant mycobiota associated with decaying leaves in streams (Godfrey 1983). Aquatic fungi have been shown to produce a rich array of enzymes able to degrade the 
major leaf polysaccharides (Suberkropp \& Krug 1980). These enzymes are able to degrade simple sugars, cellulose, and other plant polymers (Chandrashekar \& Kaveriappa 1988), and lead to skeletonization of leaves through maceration. Present investigation revealed that the fungal and chromista diversity observed is strong lignocellulose decomposers. Some tree species were colonized by more number of fungi as compared to others; this may be due to presence of less lignin in these species (Song et al. 2010). The data revealed that presence of different fungal species on various host plants differ significantly, clearly depicting some sort of host specificity in the presently studied fungal and chromista species.

Table 3 Families of different fungal and chromista species

\begin{tabular}{|c|c|c|}
\hline S. No. & Name of the species & Family assigned \\
\hline \multicolumn{3}{|c|}{ A.Fungal species } \\
\hline 1 & Aspergillus flavus & \multirow[t]{6}{*}{ Trichocomaceae } \\
\hline 2 & Aspergillus oryzae & \\
\hline 3 & Aspergillus nidulans & \\
\hline 4 & Aspergillus terreus & \\
\hline 5 & Penicillium chrysogenum & \\
\hline 6 & Penicillium sp. & \\
\hline 7 & Alternaria alternate & \multirow[t]{2}{*}{ Pleosporaceae } \\
\hline 8 & Alternaria solani & \\
\hline 9 & Cylindrocladium $\mathrm{sp}$. & \multirow[t]{7}{*}{ Nectriaceae } \\
\hline 10 & Cylindrocladium scoparium & \\
\hline 11 & Fusarium pallidoroseum & \\
\hline 12 & Fusarium oxysporum & \\
\hline 13 & Fusarium moniliforme & \\
\hline 14 & Fusarium equiseti & \\
\hline 15 & Fusarium solani & \\
\hline 16 & Scopulariopsis sp. & Microascaceae \\
\hline 17 & Trichoderma aureoviride & \multirow[t]{3}{*}{ Hypocreaceae } \\
\hline 18 & Trichoderma harzianum & \\
\hline 19 & Trichoderma viride & \\
\hline 20 & Absidia corymbifera & \multirow[t]{3}{*}{ Mucoraceae } \\
\hline 21 & Absidia sp. & \\
\hline 22 & Rhizopus oryzae & \\
\hline 23 & Curvularia lunata & Pleosporaceae \\
\hline 24 & Syncephalastrum racemosum & Syncephalastraceae \\
\hline 25 & Paecilomyces variotii & Trichocomaceae \\
\hline 26 & Verticillium nubilum & Plectosphaerellaceae \\
\hline 27 & Rhizoctonia solani & Ceratobasidiaceae \\
\hline 28 & Gliocladium $\mathrm{sp}$. & Hypocreaceae \\
\hline 29 & Periconia madreeya & \multirow[t]{5}{*}{ Incertaesedis } \\
\hline 30 & Acremonium tectonae & \\
\hline 31 & Monodictys levis & \\
\hline 32 & Gilmaniella sp. & \\
\hline 33 & Phoma exigua & \\
\hline 34 & Cylindrosporium $\mathrm{sp}$. & Dermateaceae \\
\hline \multicolumn{3}{|c|}{ B. Chromista } \\
\hline 1 & Achlya debaryana & \multirow[t]{2}{*}{ Saprolegniaceae } \\
\hline 2 & Achlya recurva & \\
\hline 3 & Althornia crouchii & Thraustochytriaceae \\
\hline 4 & Pythium debaryanum & \multirow[t]{3}{*}{ Pythiaceae } \\
\hline 5 & Pythium carolinianum & \\
\hline 6 & Pythium sp. & \\
\hline
\end{tabular}




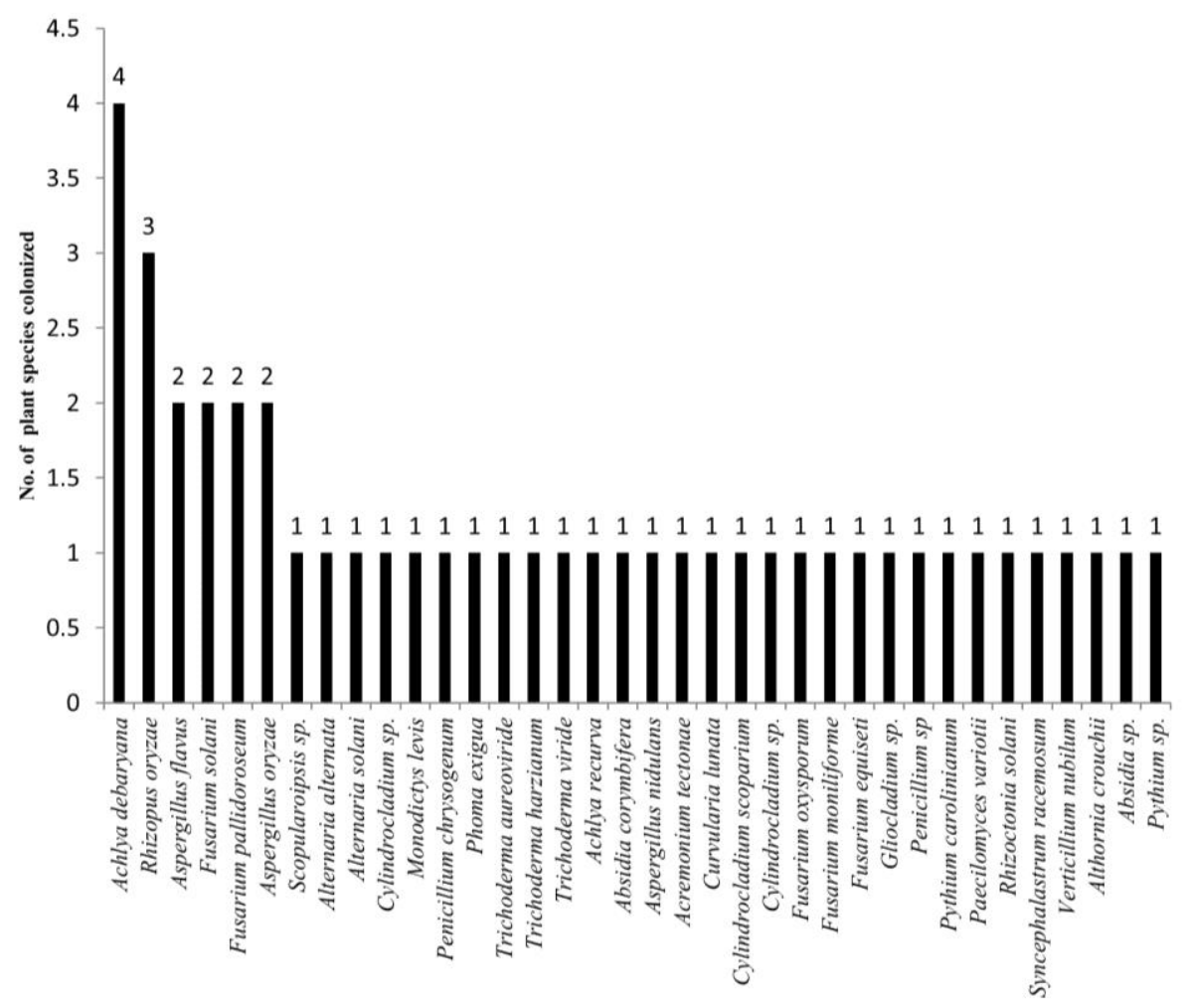

Fig. 45 - Number of plants colonized by different fungal species.

\section{No. of species}

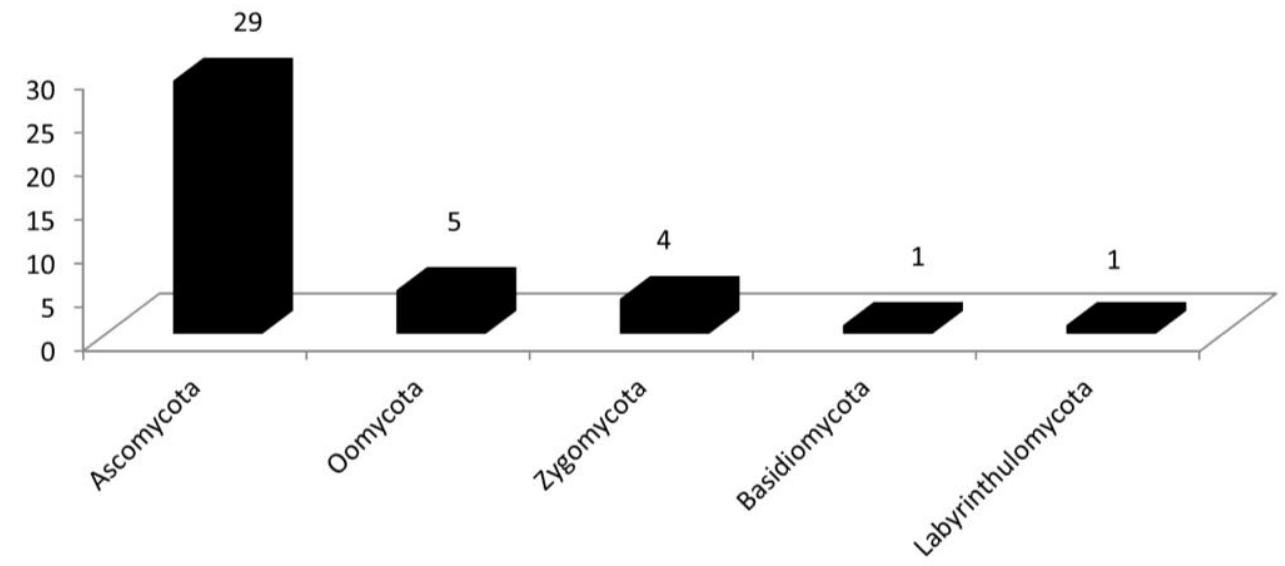

Fig. 46 - Number of species belonging to different fungal divisions.

\section{Acknowledgments}

We are highly thankful to the Heads of Department of Post Graduate Studies and Research in Biological Science, Rani Durgavati University, Jabalpur (M.P.) and Forest Pathology Division TFRI, Jabalpur, (M.P.) for providing necessary facilities.

\section{References}

Abdel-Aziz FA. 2016 - Freshwater fungi from the River Nile, Egypt. Mycosphere 7(6), 741-756, Doi 10.5943/mycosphere/7/6/4

Agarwal BL. 2008 - Basic statistics 5th edition. New Age International Publishers, Pp. 832. 
Barlocher F. 1992 - Research on aquatic hyphomycetes: historical background and overview. In: Bärlocher F (ed) The ecology of aquatic hyphomycetes. Springer, Berlin \& New York, Pp. 115 .

Barlocher F. 2009 - Reproduction and dispersal in aquatic hyphomycetes. Mycoscience 50, 3-8.

Barlocher F, Corkum M. 2003 - Nutrient enrichment overwhelms diversity effects in leaf decomposition by stream fungi. Oikos 101, 247-252.

Barlocher F, Marvanova L. 2010 - Aquatichyphomycetes (Deuteromycotina) of the Atlantic Maritime Ecozone. In: Assessment of Species Diversity in the Atlantic Maritime Ecozone. Edited by D.F. McAlpine and I.M. Smith. NRC Research Press, Ottawa, Canada, Pp. 1-37.

Barnett HL, Hunter BB. 1972 - Illustrated Genera of Imperfect fungi. Burgers publishing company, Minneapolis, minnesola (3rd ed.), Pp. 241.

Booth C. 1977 - Fusarium: Laboratory guide to the identification of the major species. Commonwealth mycological institute, Kew, surrey, England, Pp. 58.

Booth C. 1971 - The genus Fusarium. Commonwealth mycological institute, Kew, surrey, England, Pp. 237.

Borse BD. 1988 - Frequency of occurrence of marine fungi from Maharashtra coast. India. Indian Journal of Marine Sciences 17, 165-167.

Borse BD. 1987 - Marine fungi from India-IV. Transactions of the Mycological Society of Japan, $28,55-61$.

Borse BD. 2000 - Marine fungi from Maharashtra (India)-V. A checklist. J. Phytol. Res. 13 (2), 123-128.

Borse BD, Patil RV, Kelkar DJ. 1999 - Marine fungi from Diu island (India). Bris Jast 11(1), 1-8.

Brathen I. 1984 - The aquatic stauro conidial Hyphomycetes of Norway with notes on the Nordic species. Nord. J. Bot. 4, 375.

Barbosa FR, Gusmão LFP, Raja HA, Shearer CA. 2013 - New species and new records of freshwater ascomycetes from Brazil and Costa Rica. Mycologia 105(2), 335-343.

Cai L, Tsui CKM, Zhang K, Hyde KD. 2002 - Aquatic fungi from Lake Fuxian, Yunnan, China. Fungal Diversity 9, 57-70.

Calabon MS, Hyde KD, Jones EBG, Chandrasiri S et al. 2020 - www.freshwaterfungi.org, an online platform for the taxonomic classification of freshwater fungi. Asian Journal of Mycology 3(1), 419-445.

Carmichael JW, Kendrick WB, Conners IL, Sigler L. 1980 - Genera of Hyphomycetes. Alberta Press: Edmonton, Pp. 386.

Chandrashekar KR, Kaveriappa KM. 1988 - Production of extracellular enzymes by aquatic hyphomycetes. Folia Microbiol. 33, 55-58

Czeczuga B, Muszyńska E, Godlewska A, Mazalska B. 2009 - Aquatic fungi and fungus-like organisms growing on seeds of 131 plant taxa. Nova Hedwigia 89, 451-467.

Dang CK, Gessner MO, Chauvet E. 2007 - Influence of conidial traits and leaf structure on attachment success of aquatic hyphomycetes on leaf litter. Mycologia 99, 24-32.

Danger M, Gessner MO, Bärlocher F. 2016 - Ecological stoichiometry of aquatic fungi: current knowledge and perspectives. Fungal Ecol. 19, 100-111. Doi 10.1016/j.funeco.2015.09.004

Duarte S, Pascoal C, Cássio F, Baerlocher F. 2006 - Aquatic hyphomycete diversity and identity affect leaf litter decomposition in microcosms. Oecologia 147, 658-666.

Dudka IA. 1985 - Vodnyje nesovershennyje griby SSSR [Aquatic Fungi imperfecti from the Soviet Union]. Naukova Dumka, Kiev, Pp. 187, 1985. (In Russian).

Dudka IO. 1974 - Wodni hifomiceti Ukraini [Aquatic Hyphomycetes of Ukraine]. Naukova Dumka, Kiev, Pp. 239 (In Ukraine).

El-Hissy FT, El-Zayat SA, Massoud MS. 2000 - Monthly and vertical fluctuations of aquatic fungi at different depths in Aswan High Dam Lake, Egypt. In: Aquatic Mycology across the Millennium. Fungal Diversity 5, 165-173.

Ellis MB. 1971 - Dematiaceous hyphomycetes. Commonwealth mycological institute Kew, surrey, England, Pp. 608. 
Ellis MB. 1976 - More dematiaceous hyphomycetes. Commonwealth mycological institute Kew, surrey, England, Pp. 507.

Godfrey BES. 1983 - Growth of two terrestrial microfungi on submerged alder leaves. Trans. Brit. Mycol. Soc. 79, 418-421

Graca MAS. 1993 - Patterns and processes in detritus-based stream systems. Limnologica 23, 107114.

Gulis V, Marvanová L, Descals E. 2005 - An illustrated key to the common temperate species of aquatic hyphomycetes. In: Methods to Study Litter Decomposition: A Practical Guide (eds MAS Graça, F Bärlocher, MO Gessner), Kluwer Academic Publishers, The Netherlands Pp.153-167.

Goh TK, Hyde KD. 1996 - Biodiversity of freshwater fungi. Indust. Microbiol. 17, 328-345.

Grossart HP, Jimenez KR. 2016 - Aquatic fungi targeting the forgotten in microbial ecology. Current Opinion in Microbiology 31, 140-145.

Harmon ME, Franklin JF, Swanson FJ, Sollins O et al. 1986 - Ecology of coarse woody debris in temperate ecosystems. Adv Ecol Res. 15, 133-302.

Hyde KD, Goh TK. 1998a - Fungi on submerged wood in Lake Barrine, North Queensland, Australia. Mycological Research 102, 739-749.

Hyde KD, Goh TK. 1998b - Fungi on submerged wood in the River St Marie-Louis, The In: The Ecology of Aquatic Hyphomycetes (Ed. Bärlocher F.). Ecological Studies, Volume 94, Springer-Verlag, Berlin. Pp. 1-15.

Hyde KD, Maharachchikumbura SSN, Hongsanan S, Samarakoon MC et al. 2017 - The ranking of fungi: a tribute to David L. Hawksworth on his 70th birthday. Fungal Diversity 84, 1-23.

Hyde KD, Norphanphoun C, Maharachchikumbura SSN, Bhat DJ et al. 2020 - Refined families of Sordariomycetes. Mycosphere 11, 305-1059.

Index Fungorum. 2020 - http://www.indexfungorum.org/Names/Names.asp (Accessed on March 4, 2020)

Ingold CT. 1942 - Aquatic hyphomycetes of decaying alder leaves. Transactions of the British Mycological Society, 25, 339-417.

Ingold CT. 1975 - An Illustrated Guide to Aquatic and Water-Borne Hyphomycetes (Fungi Imperfecti) with Notes on their Biology. Fresh water Biological Association, Sci. Publin. No. 30. Ferry House, Ambleside, Cumbria, England. Pp. 96.

Jayasiri SC, Hyde KD, Ariyawansa HA, Bhat J et al. 2015 - The Faces of Fungi database: fungal names linked with morphology, phylogeny and human impacts. Fungal Diversity 74 (1), 318.

Jones EBG. 2006 - Form and function of fungal spore appendages. Mycoscience 47, 167-183.

Jochen PB, Zubrod JP, Ninaroder, Baschien C et al. 2019 - A glance into the black box: Novel species-specific quantitative real-time PCR assays to disentangle aquatic hyphomycete community composition. Fungal Ecology. Doi 10.1016/j.funeco.2019.08.002

Kearns SG, Baerlocher F. 2008 - Leaf surface roughness influences colonization success of aquatic hyphomycete conidia. Fungal Ecology, 1, 13-18.

Khulbe RD. 2001 - A manual for aquatic fungi, (Chytridiomycetes and Oomycetes). Daya Publishing House, New Delhi, Pp. 255.

Kiziewicz B. 2004 - Aquatic fungi and fungus-like organisms in the bathing sites of the river Supraśl in Podlasie Province of Poland. Mycologia Balcanica 1, 77-83.

Liu F, Hu DM, Cai L. 2012 - Conlarium duplumascospora gen. et. sp. nov. and Jobellisia guangdongensis sp. nov. from freshwater habitats in China. Mycologia 104(5), 1178-1186.

Luo ZL, Bao DF, Bhat JD, Yang J et al. 2016 - Sporoschisma from submerged wood in Yunnan, China. Mycological Progress 15 (10-11): 1145-1155.

Luo ZL, Hyde KD, Liu JKJ, Maharachchikumbura SSN et al. 2019 - Freshwater Sordariomycetes. Fungal Diversity 99, 451-660. 
Khallil AM, Ali EH, Hassan EA, Ibrahim SS. 2020 - Biodiversity, spatial distribution and seasonality of heterotrophic straminipiles and true zoosporic fungi in two water bodies exposed to different effluents at Assiut (Upper Egypt). Czech Mycology 72(1), 43-70

Marvanová L. 1997 - Freshwater hyphomycetes: A survey with remarks on tropical taxa. In: Tropical Mycology (eds KK Janardhanan, C Rajendran, K Natarajan, DL Hawksworth), Science Publishers, New York. Pp. 169-226.

Masigol H, Khodaparast SA, Woodhouse JN, Rojas-Jimenez K. et al. 2019 - The contrasting roles of aquatic fungi and Oomycetes in the degradation and transformation of polymeric organic matter. Limnol Oceanogr 64(6), 2662-2678

Matsushima T. 1993 - Mycological Memoirs No 7. Published by the author, Kobe, Pp. 75.

Mycobank. 2020 - www.mycobank.org (Accessed on March 4, 2020)

Nagamani A, Kunwar IK, Manoharachary C. 2006 - Handbook of soil fungi. I. K. International Publishing House Pvt. Ltd. Pp. 477.

Nilsson S. 1964 - Freshwater hyphomycetes: Taxanomy, Morphology and Ecology. Symb. Bot. Ups. 18, 1-130.

Paliwal PC, Sati SC. 2009 - Distribution of Aquatic Fungi in Relation to Physicochemical Factors of Kosi River in Kumaun Himalaya. Nature and Science 7(3), 70-74.

Raviraja NS, Nikolcheva LG, Baerlocher F. 2005 - Diversity of conidia of aquatic hyphomycetes assessed by microscopy and by DGGE. Microbial Ecol. 49, 1-7.

Read SJ, Moss ST, Jones EBG. 1992 - Attachment and germination of conidia. In: The Ecology of Aquatic Hyphomycetes (ed F Bärlocher), Springer-Verlag, Germany. 135-151.

Satyanarayana T, Johri BN. 2005 - Microbial diversity: current perspectives and potential applications. I. K. International Pvt. Ltd. Pp. 1133.

Schoenlein-Crusius IH, Milanez AI. 1998 - Fungal succession on leaves of Alchornea triplinervia (Spreng.) Muell. Arg. submerged in a stream of an Atlantic Rainforest in the state of São Paulo, Brazil. Brazalian journal of Botany. Doi 10.1590/S0100-84041998000300003

Song F, Tian X, Fan X, He X. 2010 - Decomposing ability of filamentous fungi on litter is involved in a subtropical mixed forest. Mycologia 102(1), 20-26.

Subramanian CV. 1971 - Hyphomycetes: An account of Indian species, except Cercosporae. Indian Council of Agricultural Research New Delhi, Pp. 1-930.

Sudheep NM, Sridhar KR. 2013 - Colonization and diversity of aquatic hyphomycetes inrelation to decomposition of submerged leaf litter in River Kali (Western Ghats, India). Mycosphere 4(3), 456-476. Doi 10.5943/mycosphere/4/3/3

Sparrow FK Jr. 2018 - Observations on the Aquatic Fungi of Cold Spring Harbor Mycologia 24: 268-303.

Suberkropp K, Krug MJ. 1980 - The maceration of deciduous leaf litter by aquatic hyphomycetes. Can. J. Bot. 50, 1025-1031.

Verma RK, Sharma N, Soni KK, Jamaluddin. 2008 - Forest fungi of central India. International Book Distributing Co. Pp. 418.

Webster J. 1959 - Experiments with spores of aquatic hyphomycetes: I. Sedimentation, and impaction on smooth surfaces. Annals of Botany 23, 595-611.

Xia JW, Ma YR, Li Z, Zhang XG. 2017 - Acrodictys-like wood decay fungi from southern China, with two new families Acrodictyaceae and Junewangiaceae. Scientific Reports 7, 7888.

Zhao B, Xing P, Wu QL. 2017- Microbes participated in macrophyte leaf litters decomposition in freshwater habitat. FEMS Microbiology Ecology 93 (10), 1-15. Doi 10.1093/femsec/fix 108 